\title{
Survey on packaging status and changes in quality of tomato and paprika using different packaging types
}

\author{
Min-Sun Chang ${ }^{1}$, Byung Sun $\mathrm{Lim}^{2}$, Ji Gang Kim², Gun-Hee Kim ${ }^{1 *}$ \\ ${ }^{1}$ Plant Resources Research Institute, DukSung Women's University, Seoul 01369, Korea \\ ${ }^{2}$ Postharvest Research Team, National Institute of Horticultural and Herbal Science, RDA, Wanju 55365, Korea
}

\section{토마토와 파프리카의 포장실태조사 및 포장재 종류에 따른 품질변화}

\author{
장민선 ${ }^{1} \cdot$ 임병선 $^{2} \cdot$ 김지강 $^{2} \cdot$ 김건희 $^{1 *}$ \\ ${ }^{1}$ 덕성여자대학교 식물자원연구소, ${ }^{2}$ 국립원예특작과학원 저장유통팀
}

\begin{abstract}
This study aimed to evaluate the commercialized packaging status of tomato and paprika, and to investigate the effect of different packaging materials on the quality of tomato and paprika during storage. Packaging statuses were surveyed at a department store, wholesale market, and supermarket in Seoul, Korea. Materials used for packaging tomato and paprika were cartons, polypropylene (PP), low-density polyethylene (LDPE), polystyrene (PS), and polyvinyl chloride (PVC). Tomato and paprika were packaged by using comugated boxes, Styrofoam trays, PP film, and PVC film. The weight loss and hardness of non-packaged tomato and paprika were significantly different after $48 \mathrm{hr}$ to the initial values $(\mathbf{p}<0.05)$. Box-packaged tomatoes had the lowest $\mathrm{pH}$ values and showed significantly higher soluble solid contents $(\mathbf{p}<\mathbf{0 . 0 5})$. However, there were no significant differences in among other packaging materials. For paprika, the $\Delta \mathrm{E}$ values of PVC wrapping were higher than those of other packagings. Hence, the results demonstrated that a comugated box with PP film and PP film bags with four holes plus wire-tying were most able to maintain the overall qualities of tomato and paprika, respectively, during storage.
\end{abstract}

Key words : color, quality, packaging, paprika, tomato

\section{서 론}

토마토에는 리코펜, 플라보노이드, 글루타민산, $\beta$ 카로 틴, 비타민 C와 E 등 암과 각종 성인병을 예방할 수 있는 많은 물질들이 함유되어 있으며 식이섬유 또한 풍부하다 (1). 최근 TV, 신문 등 매스컴을 통해 토마토의 효능에 대한 내용이 보도되면서 소비자의 선호도가 높아지고 작형이 다양해지며 재배면적도 꾸준히 증가하고 있는 실정이다 (2). 파프리카 또한 카로티노이드, 플라보노이드, 비타민 $\mathrm{C}$ 및 페놀화합물을 많이 함유하고 있으며 항암, 심혈관계

*Corresponding author. E-mail : ghkim@duksung.ac.kr Phone : 82-2-901-8496, Fax : 82-2-901-8474

Received 4 September 2015; Revised 4 February 2016; Accepted 11 February 2016.

Copyright (c) The Korean Society of Food Preservation. All rights reserved.
질병감소 및 예방 등 다양한 기능성이 보고되면서 최근 소비량이 늘고 있다 $(3,4)$

그러나 이들 과채류는 수확 후 저장이나 유통하는 동안 에 호흡작용, 증산작용 등의 생리작용이 활발해지고, 곰팡 이를 비롯한 미생물의 오염 및 성장으로 부패가 발생하게 된다. 이러한 부패가 진행되는 동안에 과채류 자체의 경도 가 저하되는 물리적인 변화뿐만 아니라 비타민, 유기산, 당분 등이 감소하는 영양적인 변화도 동반된다(5). 또한 품질을 저하시킬 수 있는 수분, 색소함량 등도 감소함으로 써 외관, 맛, 신선도 등이 낮아져서 상품성이 떨어지게 되므 로 과채류의 품질저하 억제를 위한 적절한 포장은 필수적이 다(2). 최근 대형유통업체의 국내진출, 대기업의 농산물 유 통시장 참여, 전자상거래와 TV 홈쇼핑 같은 디지털 유통의 도입 등으로 소비지의 농산물 유통환경이 급변하고 있으며 더욱이 국민소득이 증가됨에 따라 소비자들의 고품질·안전 농산물에 대한 수요가 증가되면서 유통업체들은 일정 등급 
의 표준규격화 된 신선하고, 안전한 농산물을 공급받기를 희망하고 있다(6).

토마토는 수확할 때 유통 중 후숙에 의해 유통기간이 단축되는 것을 염두에 두고 최숙과 이전에 수확하여 유통시 키는 것이 일반적이다. 토마토의 영양성분인 당, 산, 및 비타 민 $\mathrm{C}$ 의 최대 축적 시기는 적숙과인데 최숙과 이전에 수확되 기 때문에 저장 및 유통기간은 연장될 수 있으나 이들 함량 은 상대적으로 적어 품질 면에서 열악한 실정이다(7). 파프 리카는 수확 후 컨테이너 상자 또는 골판지 상자에 넣어져 저장 및 운송되는데 이때 저장고 및 운송 탑차 내부의 공기 에 노출되어 시들음이 빠르게 진행된다(8). 이러한 과채류 의 문제를 보완하기 위하여 항균소재를 함유한 포장재(9), 천공필름(2), 비천공 breathable 필름(10) 등을 적용한 포장 관련 연구가 진행되어왔다. 또한 일부 채소에 저장 중 필름 커버를 이용한 선도유지기술(11)이 개발되고 있으나 과채 류에 대하여 적정 필름개발 및 체계적인 적용기술 확립은 부족한 실정이다.

이에 본 연구에서는 현재 유통 중인 토마토와 파프리카 의 포장실태를 조사하고, 포장재를 달리하여 저장 중 품질 변화를 분석함으로서 선도유지에 적합한 토마토와 파프리 카의 포장방법을 개선하고자 하였다.

\section{재료 및 방법}

\section{포장실태 조사기간 및 조사방법}

토마토와 파프리카에 대한 포장 및 유통실태조사는 2014 년 6월 7월에 실시하였으며 백화점 3곳, 대형할인마트 3곳 및 슈퍼마켓 3곳 등을 직접 방문하여 포장형태, 포장재질, 포장단위, 판매대 온도 등에 대하여 조사하였다.

\section{실험재료}

본 실험에 사용한 토마토는 충남 아산에서 재배되어 10 월에 수확하였고, 파프리카는 경남 진주에서 재배되어 11 월에 수확한 것으로 실험당일 신선한 것을 구입한 후 외관 상태와 모양이 전체적으로 균일한 것을 선별하여 시료로 사용하였다.

\section{포장 및 저장}

토마토는 골판지 상자 $(300 \times 250 \times 150 \mathrm{~mm})+\mathrm{PP}$ film (30 $\mu \mathrm{m})$ 과 PP film bag+wire tying으로 포장하였고, 파프리카는 PP film bag+wire tying, 스티로폼 tray+PVC film으로 wrapping한 후(Fig. 1) 상온에서 48 시간 저장하며 품질변화 를 측정하였다.

\section{품질특성 분석 \\ 중량감모율 \\ 초기중량과 일정기간 경과 후 측정된 시료의 중량 차이}

를 초기중량에 대한 백분율(\%)로 나타내었다.
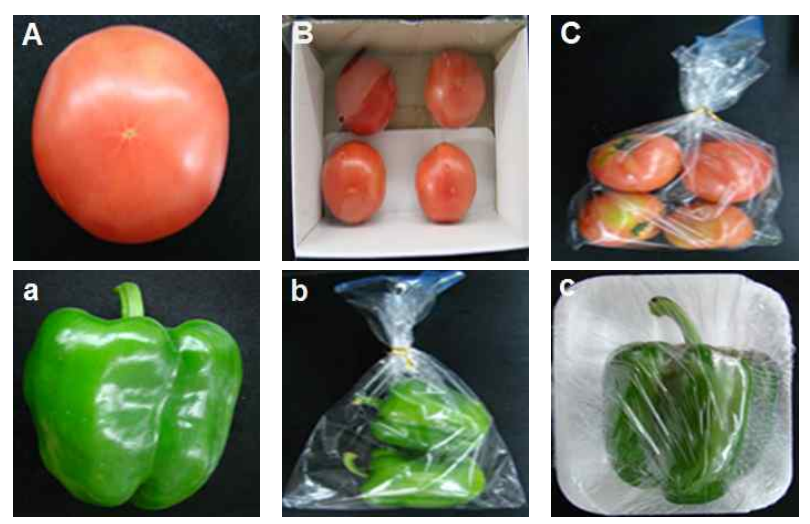

Fig. 1. Packaging types for tomato and paprika.

A, tomato_Control; B, tomato_Corrugated box+PP film; C, tomato_PP film bag (wire-tying); a, paprika_Control; b, paprika_PP film bag (wire-tying); c, paprika_Styrofoam tray+PVC film wrapping.

\section{표면색도}

표면색은 표준백판 $(\mathrm{L}=97.40, \mathrm{a}=-0.49, \mathrm{~b}=1.96)$ 으로 보정 된 chromameter(CR-400, Minolta Co., Osaka, Japan)를 사용 하여 측정하였으며, 시료 표면의 중심부위를 10 반복으로 Hunter 색차계인 L, a 및 b값을 측정하였다. 각 처리구간의 색도의 차이는 색차(color difference, $\triangle \mathrm{E}$ )를 이용하여 분석 하였으며 계산식은 다음과 같다.

$$
\Delta \mathrm{E}=\left(\Delta \mathrm{L}^{2}+\Delta \mathrm{a}^{2}+\Delta \mathrm{b}^{2}\right)^{1 / 2}
$$

경도

저장기간 중 토마토 및 파프리카의 경도측정을 위하여 직경 $5 \mathrm{~mm}$ 의 probe를 장착한 texture analyser(LLOYD Instrument, Ametek, Inc., Fareham, UK)를 이용하여 토마토 는 표면의 적도부분을 측정하였고, 파프리카는 시료의 중 간부분을 측정하였으며 depression limit $10 \mathrm{~mm}$, test speed $50 \mathrm{~mm} / \mathrm{min}$, trigger $0.1 \mathrm{~N}$ 의 조건에서 측정하였다.

\section{가용성 고형분, $\mathrm{pH}$, 산도}

토마토를 착즙하고 여과한 액을 취해 식품당도측정기 (GMK-703F, G-won Hitech Co., Seoul, Korea)를 사용하여 측정하였다. $\mathrm{pH}$ 및 산도는 시료를 3 겹의 거즈를 사용하여 여과한 후 여과된 시료즙액 $10 \mathrm{~mL}$ 를 경시적으로 취하여 $\mathrm{pH}$ 와 산도는 $\mathrm{pH}$ meter(Orion $3 \mathrm{star}$, Thermo, USA)로 측정하 였다.

\section{통계처리}

본 연구결과에 대한 통계처리는 SPSS Win Program (Version 19.0, USA)을 이용하여 평균과 표준편차로 표시하 였으며, t-test 및 Duncan's multiple range test를 실시하여 
유의성을 검정하였다.

\section{결과 및 고찰}

\section{포장실태}

과채류의 포장실태조사 결과는 Table 1에 나타내었으며 토마토의 경우 주로 골판지 상자, 골판지 상자+PP film, PP film bag, PS 또는 스티로폼 용기에 PVC film으로 wrapping 된 소포장 형태로 판매되고 있었다. Film에는 6 $\mathrm{mm}$ 직경의 hole이 있었으며 film bag에 포장된 경우 완숙된 토마토가 많았고, 표면이 다소 물러진 상태로 품질이 저하 되어 있었다. 파프리카는 상자보다 PP film bag이나 PS, 스티로폼에 PVC wrapping 된 형태로 주로 판매되고 있었으 며 이 경우 냉장온도 $\left(5^{\circ} \mathrm{C}\right)$ 에 진열되어 있었다.

백화점, 대형할인마트, 슈퍼마켓 등에서 모두 판매대 위 에 올려놓고, 상온에서 소비자가 원하는 만큼의 양을 LDPE 또는 미세천공이 있는 HDPE film bag에 담아서 판매하고 있었는데 이 경우 토마토와 파프리카가 외부조건에 그대로 노출되어있고, 표면에 손이 닿으면서 빠른 품질변화를 초 래할 가능성이 높았다. 또한, 백화점 및 대형할인마트에서

Table 1. Status of packaging types for different production area of fruits and vegetables

\begin{tabular}{|c|c|c|c|c|}
\hline Area & & Packaging types & Weight & Temperature \\
\hline \multirow{6}{*}{$\begin{array}{l}\text { Department } \\
\text { store }\end{array}$} & \multirow{4}{*}{ Tomato } & Corrugated box $+\mathrm{PP}^{1)}$ film & $2 \mathrm{~kg}$ & \multirow{4}{*}{$\begin{array}{c}\text { Room } \\
\text { temperature }\end{array}$} \\
\hline & & Corrugated box + PP film (4 holes) & $2 \mathrm{~kg}$ & \\
\hline & & PP film bag (4 holes) & 8 ea & \\
\hline & & $\mathrm{LDPE}^{2)}$ film bag & - & \\
\hline & \multirow{2}{*}{ Paprika } & $\mathrm{PS}^{3)}$ tray $+\mathrm{PVC}^{(1)}$ film & $1 \sim 2$ ea & $5^{\circ} \mathrm{C}$ \\
\hline & & LDPE film bag & - & $\begin{array}{c}\text { Room } \\
\text { temperature }\end{array}$ \\
\hline \multirow{6}{*}{$\begin{array}{c}\text { Wholesale } \\
\text { market }\end{array}$} & \multirow{4}{*}{ Tomato } & Corrugated box & $5 \mathrm{~kg}$ & \multirow{4}{*}{$\begin{array}{c}\text { Room } \\
\text { temperature }\end{array}$} \\
\hline & & Corrugated box + PP film (4 holes) & $2 \mathrm{~kg}$ & \\
\hline & & Styrofoam tray + PVC film & $1 \mathrm{~kg}$ & \\
\hline & & PP film bag (4 holes) & $1.2 \mathrm{~kg}$ & \\
\hline & \multirow[t]{2}{*}{ Paprika } & Microperforated $\mathrm{HDPE}^{5)}$ film bag & - & $\begin{array}{c}\text { Room } \\
\text { temperature }\end{array}$ \\
\hline & & PP film bag & 2 ea & $5^{\circ} \mathrm{C}$ \\
\hline \multirow{4}{*}{ Supermarket } & \multirow{2}{*}{ Tomato } & Corrugated box & $5 \mathrm{~kg}$ & \multirow{2}{*}{$\begin{array}{c}\text { Room } \\
\text { temperature }\end{array}$} \\
\hline & & Styrofoam tray + PVC film & 6 ea & \\
\hline & \multirow{2}{*}{ Paprika } & PP film bag (wire-tying) & 3 ea & \multirow{2}{*}{$5^{\circ} \mathrm{C}$} \\
\hline & & Styrofoam tray + PVC film & 2 ea & \\
\hline \multicolumn{5}{|c|}{$\begin{array}{l}\text { 1) PP, polypropylene. } \\
{ }^{2)} \mathrm{LDPE} \text {, low density polyethylene. } \\
{ }^{3)} \mathrm{PS} \text {, polystyrene. } \\
{ }^{4)} \mathrm{PVC} \text {, polyvinyl chloride. } \\
{ }^{5)} \mathrm{HDPE} \text {, high density polyethylene. }\end{array}$} \\
\hline
\end{tabular}

는 상자 형태로 대량 판매되고 있었고, 슈퍼마켓에서는 소 포장 단위로 주로 판매되고 있었다(Fig. 2).

\section{중량감모율}

포장방법에 따른 48 시간 동안 토마토의 중량감모율을 측정한 결과는 Fig. $3 \mathrm{~A}$ 와 같으며 포장하지 않은 토마토의 중량감모율이 월등히 높았고, 저장 48 시간 후에는 저장 24 시간 후의 감모율에 비해 약 2 배 이상의 값을 나타냈다. Box 포장과 PP film bag으로 포장한 경우, 저장 24시간 후부터 유의적인 차이가 나지 않는 범위 내에서 중량감모율 이 증가하였고, 포장으로 인하여 중량감모가 적게 일어났 음을 알 수 있었다. 저장 48시간 후 포장방법에 따른 중량감 모율을 비교하였을 때, control > PP film bag $\geq$ box 순으로 높은 값을 나타내며 유의적인 차이를 보였다( $\mathrm{p}<0.05)$. 이는 저장 중인 토마토의 중량감모가 필름포장 한 처리구에서 낮다는 Park 등(12)의 보고와도 일치하였다.

파프리카의 경우, 포장하지 않은 control군의 중량감모가 PP film bag 및 tray에 wrapping 된 파프리카보다 월등히 높았고, 포장하지 않은 파프리카는 저장 24시간에서 48시 간 경과 시 약 4 배 정도의 높은 중량감모의 폭을 보이며 처리군 중에서 가장 큰 중량감모율을 나타내었다(Fig. 3B). PP film bag 및 tray에 wrapping하여 저장한 파프리카는 저 장시간 경과에 따른 유의적인 차이를 보였으며 $(\mathrm{p}<0.05)$ 저 장 48 시간 후 포장방법에 따른 중량감모율을 비교하였을 때 control > PP film bag > tray에 wrapping 순으로 높은 값을 나타내었다. 파프리카는 $4 \%$ 이상의 수분손실로도 과 피가 연약해지며 상품성을 잃게 되는데(13), 본 연구에서는 포장하지 않은 control군을 제외한 PP film bag 및 tray에 wrapping된 파프리카의 경우 저장기간 동안 약 $3 \%$ 이하의 중량감모율을 보여 수분손실로 인한 상품성 손실은 없었던 것으로 판단된다. 또한 과채류의 저장 중 중량감모는 증산 작용에 의한 것으로 필름으로 포장한 처리구 내부의 호흡이 억제되고 상대습도가 높아 수분증발이 다소 억제된 것으로 사료된다.

Table 2. Changes in tomato color in different packaging types during storage at room temperature

\begin{tabular}{|c|c|c|c|c|c|}
\hline $\begin{array}{l}\text { Storage } \\
\text { periods }\end{array}$ & $\begin{array}{l}\text { Packaging } \\
\text { types }\end{array}$ & $\mathrm{L}$ & $\mathrm{a}$ & $\mathrm{b}$ & $\Delta \mathrm{E}$ \\
\hline 0 hour & Control & $39.78 \pm 1.51^{1)}$ & $13.41 \pm 2.48$ & $11.80 \pm 0.93$ & 0 \\
\hline \multirow{3}{*}{48 hours } & Control & $35.54 \pm 1.45$ & $18.32 \pm 0.69^{* * * 2)}$ & $9.98 \pm 0.58$ & $7.69 \pm 0.59^{\text {b3) }}$ \\
\hline & Box & $35.32 \pm 0.99$ & $18.15 \pm 1.12^{* *}$ & $10.02 \pm 0.58$ & $6.90 \pm 0.62^{\mathrm{a}}$ \\
\hline & PP film bag & $34.44 \pm 1.01$ & $18.12 \pm 1.28^{*}$ & $9.42 \pm 0.74$ & $6.89 \pm 0.28^{\mathrm{a}}$ \\
\hline
\end{tabular}


A
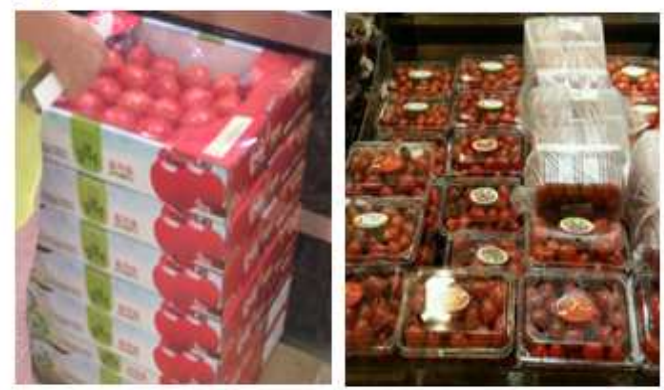

B
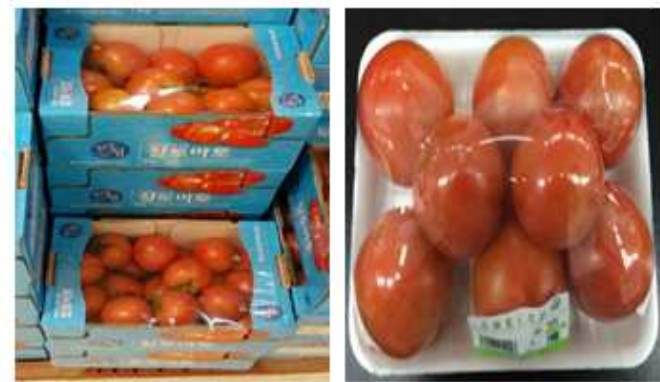

C
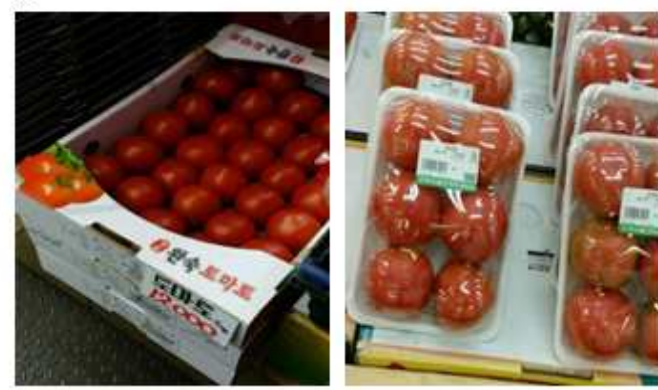
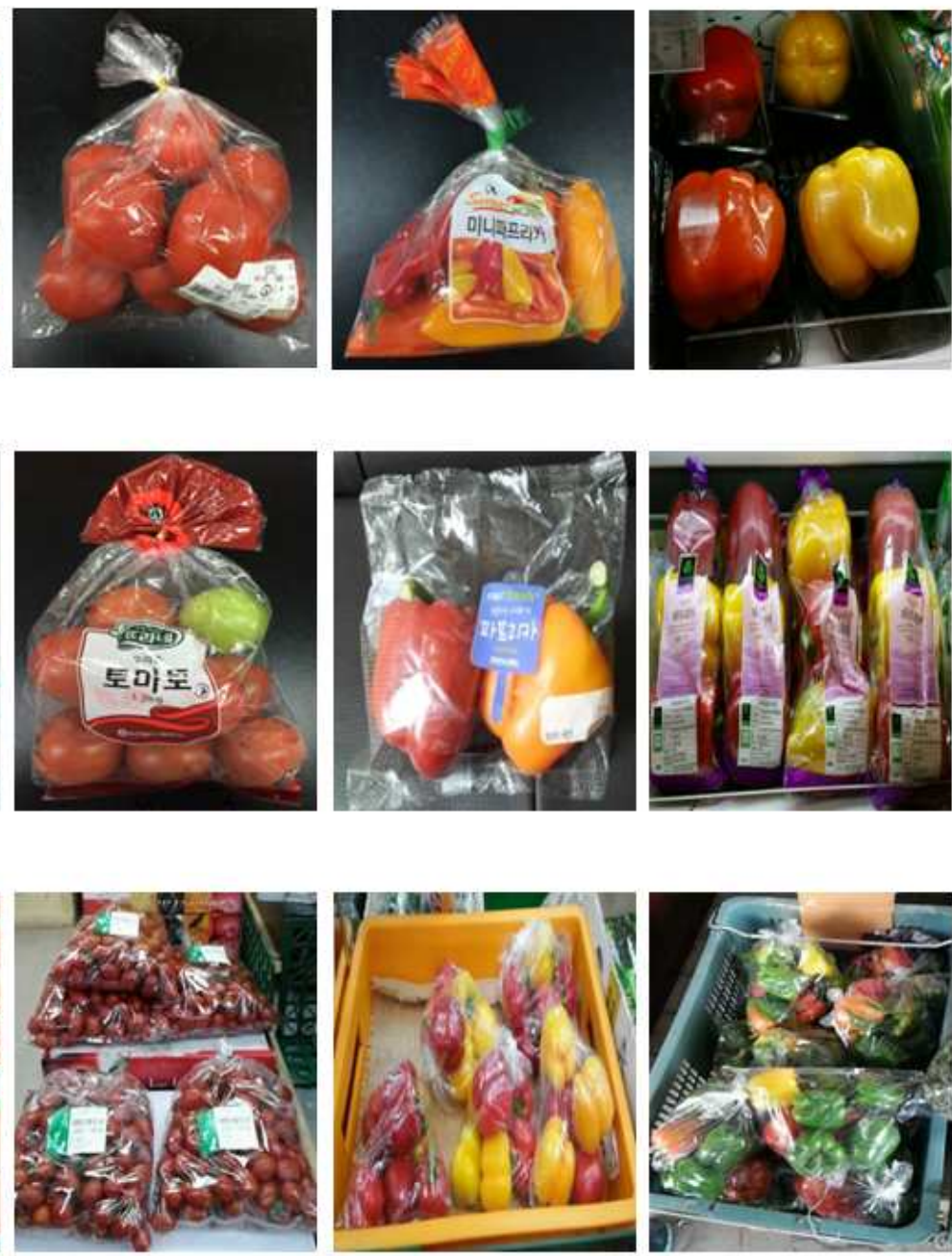

Fig. 2. Packaging types for different production areas of fruits and vegetables.

A, department store; B, wholesale market; $\mathrm{C}$, supermarket.

\section{표면색도}

포장재질에 따른 토마토의 표면색도를 측정한 결과는 Table 2와 같으며 저장 48 시간 후 $\mathrm{a}$ 값이 모든 처리구에서 초기보다 증가되었고, 처리구에 따른 유의적인 차이를 나 타내었다. 저장 48 시간 후 $\mathrm{L}$ 과 $\mathrm{b}$ 값은 감소하였으며 처리구 에 따른 유의적인 차이는 없었다. Moon 등(14)의 연구에서 도 $\mathrm{a}$ 값의 경우 저장기간 중 전반적으로 증가하는 경향을 보였고, $\mathrm{L}$ 과 $\mathrm{b}$ 값의 경우 대체로 감소하였다고 보고하여 본 실험결과와 유사하였다. 또한 저장시간에 따른 전체 색 변화인 $\Delta \mathrm{E}$ 값에 있어서 포장하지 않은 토마토에서 7.69로 색 변화가 가장 많이 일어났으며 box 포장한 경우는 6.90 , PP film bag으로 포장한 경우는 6.89로 가장 낮은 색 변화를 보였으며 유의적인 차이를 보였다(p<0.05). 육안으로 보았 을 때 옅은 주황색을 띠고 있었던 초기 색에 비해 저장 48시간 후, 붉은 색을 띠고 있어 저장기간 동안 숙성이 되었
음을 확인할 수 있었으나 포장방법에 따른 외관상 큰 차이 는 없었다(Fig. 4).

파프리카의 표면색도를 측정한 결과는 Table 3 과 같으며 초기 값에 비해 $\mathrm{L}$ 과 $\mathrm{b}$ 값은 감소, $\mathrm{a}$ 값은 증가하는 경향을 보였다. $\mathrm{L}$ 과 $\mathrm{a}$ 값의 경우 tray에 wrapping한 처리구에서 초기 값과의 유의적인 차이를 보였다. $\Delta \mathrm{E}$ 값의 경우, tray에 wrapping $>$ control $\geq$ PP film bag 순으로 높은 값을 보여 tray에 wrapping한 토마토에서 저장시간 동안 색 변화가 가장 많이 일어났음을 알 수 있었으며 PP film bag으로 포장 한 토마토의 색 변화가 가장 적었고, 처리구간에 따른 유의 적인 차이를 보였다(p<0.05). Fig. 5 에서 관찰할 수 있듯이, 파프리카의 외관은 wrapping 처리구에서 저장시간이 경과 함에 따라 다소 붉은 빛으로 변한 것을 확인할 수 있었으며 이로 인해 $\Delta \mathrm{E}$ 값이 역시 다른 처리구의 값보다 약 2 배 이상 으로 높았고, 다른 처리구에 비하여 호흡속도가 빠르게 

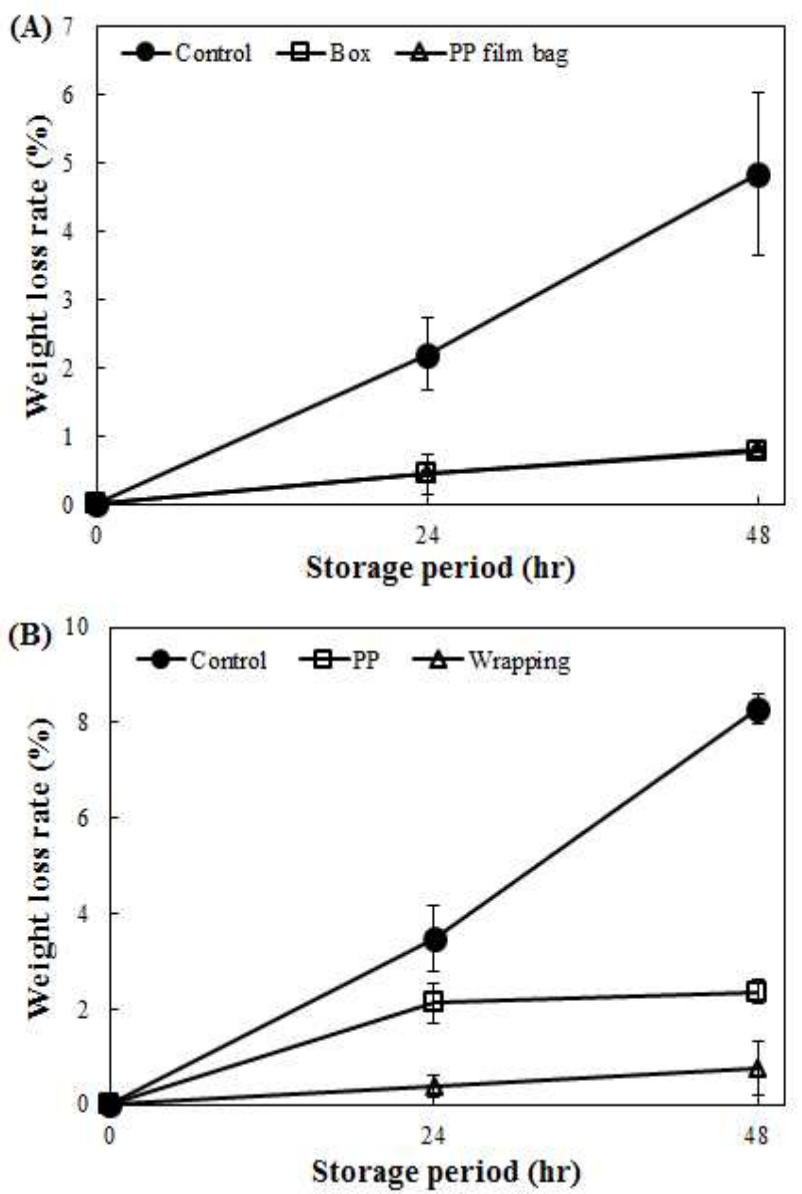

Fig. 3. Changes in the weight-loss rate of tomato (A) and paprika (B) in different packaging types during storage at room temperature.

${ }^{a-b}$ Values with different letters within date of $48 \mathrm{hr}$ are significantly different from each other ( $p<0.05$, Duncan's test).
진행되어 색 변화가 많이 일어난 것으로 판단되어 이 포장 방법은 파프리카의 품질유지에는 다소 효과적이지 않은 것으로 사료된다.

\section{경 도}

포장방법에 따른 48시간 동안 토마토의 경도를 측정한 결과는 Fig. 6과 같으며 24시간 후에 약간 증가하였다가 48 시간 후에 급감하는 양상을 보였다. 저장 48 시간 후 모든 처리구에서 유의적으로 경도가 감소하였으며 $(\mathrm{p}<0.001)$, box > PP film bag > control 순으로 높은 경도를 나타내며 box 포장이 토마토의 경도 유지에 가장 효과적인 것으로 조사되었다. 이러한 경도 감소는 토마토의 수축으로 인하 여 외관에도 영향을 끼치므로 소비자들이 토마토 구매를 결정하는 중요한 요소 중 하나로 작용하기도 한다(15).

파프리카의 경도결과는 Table 4에 제시하였으며 저장 48 시간 후 control군의 경도가 $6.29 \mathrm{~N}$ 으로 가장 낮았으며,

Table 3. Changes in paprika color in different packaging types during storage at room temperature

\begin{tabular}{cccccc}
\hline $\begin{array}{c}\text { Storage } \\
\text { periods }\end{array}$ & $\begin{array}{c}\text { Packaging } \\
\text { types }\end{array}$ & $\mathrm{L}$ & $\mathrm{a}$ & $\mathrm{b}$ & $\Delta \mathrm{E}$ \\
\hline 0 hour & Control & $31.09 \pm 3.42^{1)}$ & $-8.25 \pm 1.38$ & $10.33 \pm 2.51$ & 0 \\
\hline \multicolumn{7}{c}{ Control } & $\left.30.06 \pm 2.06^{\mathrm{ab} 3}\right)$ & $-7.11 \pm 1.26^{\mathrm{b}}$ & $9.19 \pm 1.98^{\mathrm{a}}$ & $3.20 \pm 1.64^{\mathrm{a}}$ \\
48 hours & PP film bag & $30.43 \pm 2.20^{\mathrm{a}}$ & $-7.56 \pm 1.59^{\mathrm{b}}$ & $9.89 \pm 2.10^{\mathrm{a}}$ & $2.98 \pm 1.85^{\mathrm{a}}$ \\
& Wrapping & $28.71 \pm 1.83^{* * 22) \mathrm{c}}$ & $-2.17 \pm 2.27^{* * \mathrm{a}}$ & $7.62 \pm 1.68^{\mathrm{b}}$ & $7.72 \pm 0.91^{\mathrm{b}}$ \\
\hline
\end{tabular}

${ }^{1)}$ All data are reported as Mean $\pm \mathrm{SD}, \mathrm{n}>3$.

${ }^{2)^{*}, * *,+* * *}$ Values are significantly different from that of the $0 \mathrm{hr}(\mathrm{p}<0.05,<0.01$, $<0.001$ t-test)

${ }^{3) a-c}$ Values with different letters within a column are significantly different from each other ( $\mathrm{p}<0.05$, Duncan's test).
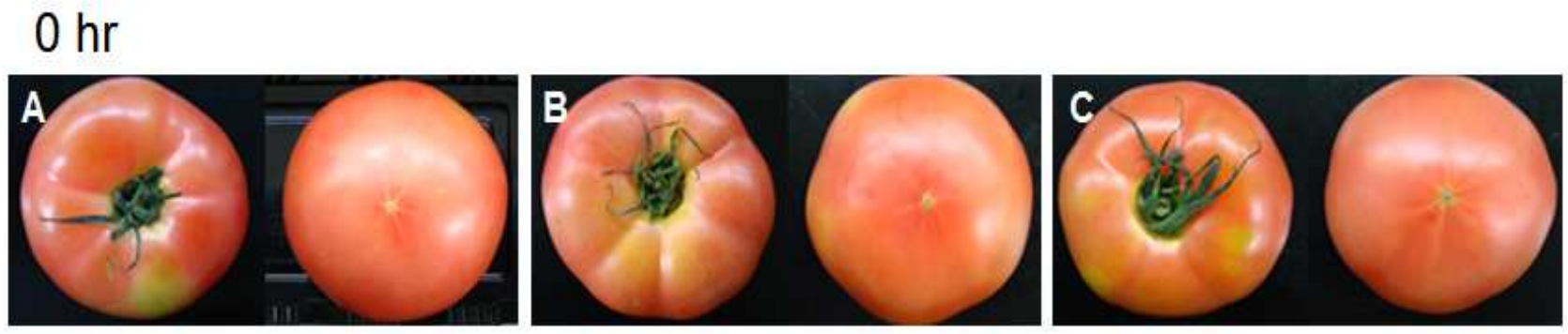

\section{After $48 \mathrm{hr}$}
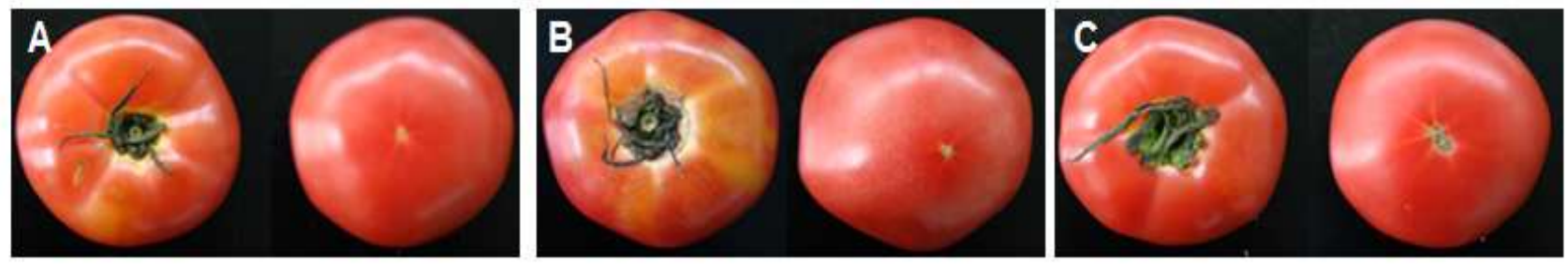

Fig. 4. Changes in tomato appearance in different packaging types during storage at room temperature.

A, Control; B, Corrugated box+PP film; C, PP film bag (wire-tying) 

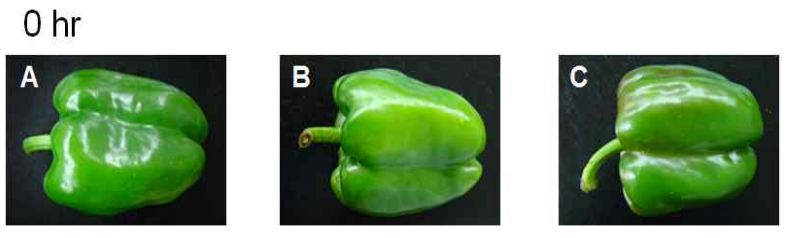

After $48 \mathrm{hr}$
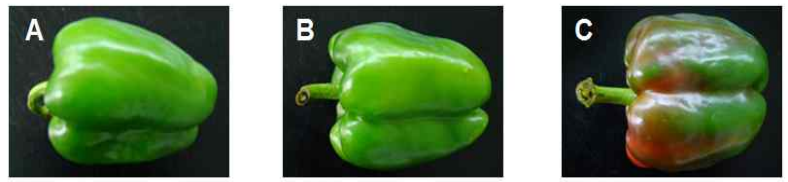

Fig. 5. Changes in paprika appearance in different packaging types during storage at room temperature.

A, Control; B, PP film bag (wire-tying); C, Styrofoam tray+PVC film wrapping

tray에 wrapping > PP film bag > control 순으로 경도 값이 높았고, 포장종류에 따른 유의적인 차이를 보였다 $(\mathrm{p}<0.05)$. 이는 중량감모율의 역순과 유사한 경향이었다. 과채류의 연화는 펙틴물질의 가용화와 세포벽 성분들의 변화 등이 주요 원인으로 작용하며 Park 등(16)이 보고한 파프리카를 $\mathrm{PLA}$ 및 OPP 필름으로 포장한 파프리카의 저장 중 경도감 소 결과와도 유사하였다.

가용성 고형분, $\mathrm{pH}$, 산도

토마토에 대하여 저장 중의 가용성 고형분, $\mathrm{pH}$, 산도 등을 측정하였으며 그 결과는 Fig. 7과 같다. 가용성 고형분 의 경우 저장시간이 경과함에 따라 control에서만 감소하였 고, 다른 처리구에서는 저장 중 다소 증가하는 양상을 보여 포장의 유·무에 따른 확연한 차이를 보였다( $\mathrm{p}<0.05)$. 저장 48시간 후, box $\geq$ PP film bag > control 순으로 가용성 고형분 함량이 높았다(Fig. 7A). 이는 control을 제외한 포장

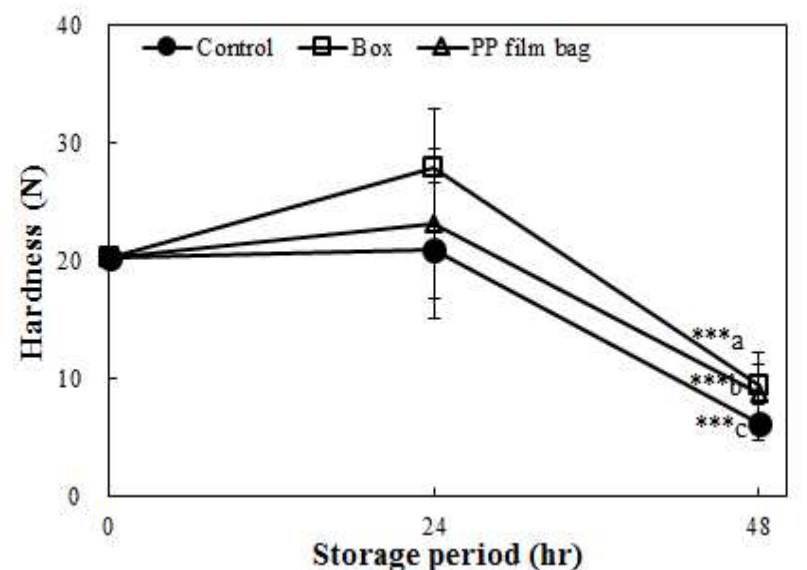

Fig. 6. Changes in tomato hardness in different packaging types during storage at room temperature.

${ }^{a-b}$ Values with different letters within date of $48 \mathrm{hr}$ are significantly different from each other ( $\mathrm{p}<0.05$, Duncan's test). t-test).
Table 4. Changes in paprika hardness in different packaging types during storage at room temperature

\begin{tabular}{ccc}
\hline \multirow{2}{*}{ Packaging types } & \multicolumn{2}{c}{ Storage period } \\
\cline { 2 - 3 } & 0 hour & After 48 hours \\
\hline Control & $15.73 \pm 3.53^{1)}$ & $6.29 \pm 1.55^{* * \times 2)(3)}$ \\
PP film bag & $15.73 \pm 3.53$ & $11.28 \pm 1.33^{\mathrm{b}}$ \\
Wrapping & $15.73 \pm 3.53$ & $13.26 \pm 2.48^{\mathrm{a}}$ \\
\hline
\end{tabular}

${ }^{1)}$ All data are reported as Mean $\pm \mathrm{SD}, \mathrm{n}>3$.

${ }^{2)^{* * *}}$ Values are significantly different from that of the $0 \mathrm{hr}(\mathrm{p}<0.001 \mathrm{t}$-test).

${ }^{3) \text { a-c }}$ Values with different letters within the same column are significantly different each other ( $p<0.05$, Duncan's test).

처리구에서 토마토의 초기 가용성 고형분이 $4.2{ }^{\circ} \mathrm{Brix}$ 에서 저장기간이 경과함에 따라 $4.3 \sim 4.7{ }^{\circ} \mathrm{Brix}$ 까지 증가했다는 Moon 등(15)의 결과와 유사하였다. 그러나 Jeong 등(7)이 연구한 기능성 포장지에 의한 토마토 품질유지 결과와 Park 등(12)이 연구한 기능성 modified atmosphere (MA) 필름으 로 포장한 토마토의 신선도 연구에서 저장 중 토마토의 가용성 고형분이 저장기간이 길어짐에 따라 다소 감소하는 경향을 보인 결과와는 다소 차이를 보였으나 이는 토마토 숙도, 구입 시기, 품종 등의 차이에 따른 것으로 판단된다.

저장 중 토마토의 $\mathrm{pH}$ 는 48 시간 동안 증가하는 경향을 보이나 control에서는 저장 24시간 후부터 다소 유지되는 양상을 보였으며 초기 값과 48 시간 후의 $\mathrm{pH}$ 를 비교하였을 때, control 처리구에서 유의적인 차이를 보이며 증가하였다 (Fig. 7B). 저장 48시간 후 control > PP film bag > box 순으로 $\mathrm{pH}$ 가 높게 조사되었으나 유의적 차이는 없었다. 이는 저장 기간이 경과함에 따라 다소 증가하다가 감소하는 경향을 나타낸 Park 등(5)의 연구와 토마토의 초기 $\mathrm{pH}$ 가 4.1이고, 저장 중 다소 증가한다는 Moon 등(15)의 결과와 유사하였다.

저장 중 토마토의 산도변화는 Fig. $7 \mathrm{C}$ 과 같이, control 처리구에서 다른 처리구에 비해 산도 감소가 큰 것으로 조사되었으며 전체적으로 box > PP film bag > control 순으 로 산도가 높았다. 가용성 고형분과 산도의 변화는 밀접한 상관관계를 보이며 포장하지 않은 control의 토마토는 저장 시간이 길어질수록 산도가 감소하다가 일정수준을 유지하 고, 가용성 고형분은 일정수준을 유지하다가 감소되는 반 면, box 및 PP film bag으로 포장한 토마토에서는 산도가 천천히 증가하거나 비슷한 수준으로 유지되고, 가용성 고 형분은 증가하는 변화를 나타냈다.

\section{요 약}

본 연구에서는 과채류의 포장실태를 조사하고, 포장방법 을 달리한 토마토 및 파프리카의 저장 중 품질변화를 측정 하였다. 포장실태조사는 서울에 소재한 백화점, 대형할인 마트, 동네슈퍼마켓을 대상으로 조사하였으며 주로 골판지 
상자, PP, LDPE, PS, PVC 등의 재질로 포장되어 있었다. 이를 바탕으로 토마토와 파프리카의 포장형태별 품질변화 를 측정하기 위하여 토마토는 골판지 상자+PP film, PP film $\mathrm{bag}$, 파프리카는 PP film bag, 스티로폼 tray+PVC film wrapping 형태로 포장한 후 상온저장하며 품질변화를 측정
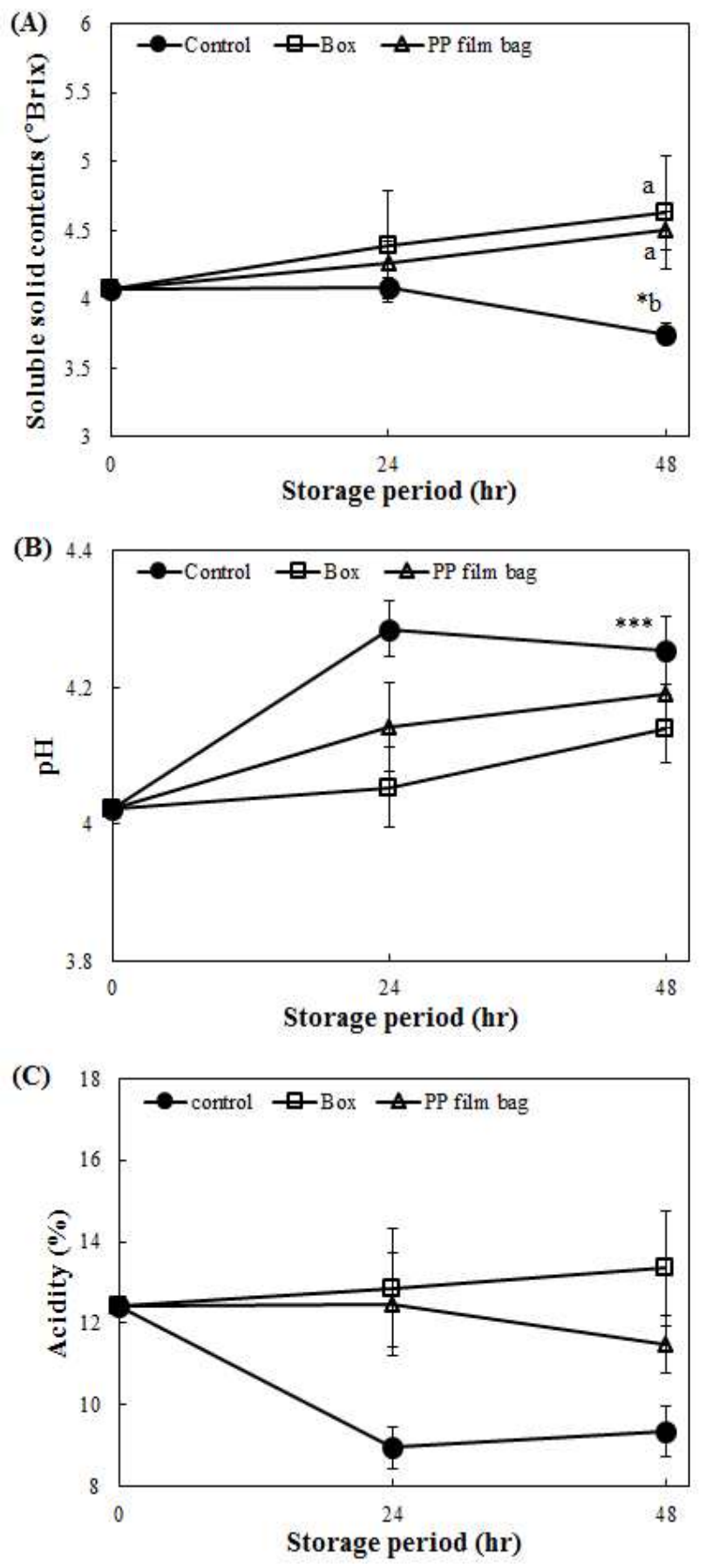

Fig. 7. Changes in SSC (A), pH (B) and acidity (C) of tomato in different packaging types during storage at room temperature.

${ }^{a-b}$ Values with different letters within date of $48 \mathrm{hr}$ are significantly different from

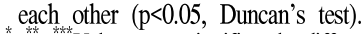
t-test).
하였다. 저장 48시간 후 포장하지 않은 토마토와 파프리카 의 중량감모율이 다른 처리구에 비하여 증가하였으며 경도 는 저장 중 감소하였다. 골판지 상자로 포장한 토마토는 저장 중 가용성 고형분 함량이 유의적으로 높았던 반면, $\mathrm{pH}$ 값은 처리구 중에서 가장 낮았으며 유의적인 차이는 없 었다. 토마토는 골판지 상자+PP film, 파프리카는 PP film $\mathrm{bag}$ 으로 포장한 경우 저장 중 품질유지에 효과적이었다.

\section{감사의 글}

본 논문은 농촌진흥청 공동연구사업의 연구비 지원 (PJ0102362015)을 받아 수행된 연구로 이에 감사드립니다.

\section{References}

1. Park SW, Lee JW, Kim YC, Kim KY, Hong SJ (2004) Changes in fruit quality of tomato 'dotaerang' cultivar during maturation and postharvest ripening. Korean $\mathrm{J}$ Hort Sci Technol, 22, 381-387

2. Choi WS, Hwang KT, Kim KM (2009) Prolongation of cherry tomato shelf-life using perforated film packaging. Korean J Food Preserv, 16, 139-146

3. Kim SH, Park JM, Yoon HS, Song DN, Song IG, Eom HJ (2013) Physiological and sensory characteristics of Makgeolli with added paprika (Capsicum annuum L.). Korean J Food Sci Technol, 45, 578-582

4. Park JH, Kim S, Moon BK (2011) Changes in carotenoids, ascorbic acids, and quality characteristics by the pickling of paprika (Capsicum Annuum L.) cultivated in Korea. J Food Sci, 76, 1075-1080

5. Park WP, Kim CH, Cho SH (2006) Quality characteristics of cherry tomato and Unshiu orange packaged with box incorporated with antimicrobial agents. Korean J Food Preserv, 13, 273-278

6. Chang MS, Lee DU, Cho SD, Jhune CS, Kim GH (2012) Survey on packaging status and effects of precooling on the quality of Agaricus bisporus. Korean J Food Preserv, 19, 67-73

7. Jeong CS, Park SM, Yun IJ, Park JN, Lee SJ, Lee SJ (2005) Effects of functional packaging paper on quality maintenance of tomato fruit during simulated marketing. Korean J Hortic Sci Technol, 23, 26-30

8. Cho MA, Hong YP, Kweon HJ, Pae DH (2008) Effect of MA films with high permeability rate on quality of paprika during storage. Abstract of 89th conference of 
the Korean J Hortic Sci Technol, Seoul, Korea, p 44

9. Park WP, Cho SW, Kim CH (2004) Quality Characteristics of cherry tomatoes packaged with paper bag incorporated with antimicrobial agents. J Korean Soc Food Sci Nutr, 33, 1381-1384

10. Choi IL, Yoo TJ, Kim IS, Lee YB, Kang HM (2011) Effect of non-perforated breathable films on the quality and shelf life of paprika during MA storage in simulated long distance export condition. J Bio-Environment Control, 20, 150-155

11. Kim JG, Choi JW, Kim WB, Park MH, Kim YP, Yoon MK (2013) Effect of the plastic film and moisture absorption paper on the quality of autumn harvest-kimchi cabbage during storage. Abstract of 89th conference of the Korean J Hortic Sci Technol, Suncheon, Korea, p 76-77

12. Park HW, Kim SH, Cha HS, Kim YH, Lee SA, Rabie
SM (2006) Freshness of tomato cultivated in Egypt by packaging functional MA film. J Korean Soc Packaging, $12,41-44$

13. Choi IL, Yoo TJ, Jung HJ, Kim IS, Kang HM, Lee YB (2011) Effects of active modified atmosphere packaging on the storability of fresh-cut paprika. J Bio-Environment Control, 20, 227-232

14. Moon KD, Lee CH, Kim JK, Sohn TH (1992) Storage of tomatoes by polyethylene film packaging and $\mathrm{CO}_{2}$ treatment. Korean J Food Sci Technol, 24, 603-609

15. Saha S, Hedau NK, Mahajan V, Singh G, Gupta HS, Gahalain A (2010) Textural, nutritional and functional attributes in tomato genotypes for breeding better quality varieties. J Sci Food Agric, 90, 239-244

16. Park HW, Kim SH, Lee SA (2011) Freshness of paprika packed with PLA films. Korean J Packaging Sci Technol, $17,7-11$ 